\title{
From the 19th-Century Novel to the Portuguese Contemporary
}

\section{Film Adaptation*}

\author{
Filomena A. Sobral \\ Polytechnic Institute of Viseu, Viseu, Portugal \\ Porto Regional Center of the Portuguese Catholic University, Porto, Portugal
}

\begin{abstract}
The literary adaptations of canonical novels for film provide a unique repository of both identity contents and socio-cultural observations which can be revisited through the filmic representations. These recreations symbolize not only a privileged visual interpretation of a nation, but they also allow us to examine how a given society reflects itself through the fiction. In this sense, the objective of this paper is to reflect upon the Portuguese updated filmic adaptation of The Crime of Father Amaro (1880) by the canonical author Eça de Queiroz. On one hand, the author intends to rethink about the Portuguese identity portrayed by the film and, at the same time, the author manages to observe how the Portuguese society is revealed. On the other hand, the paper aims to analyze the particular process of the adaptation of The Crime of Father Amaro following a qualitative methodology.
\end{abstract}

Keywords: cinema, adaptation, literature, Eça de Queiroz, classical novels

\section{Introduction}

Cinema has always been based on literary material as a source of inspiration for some of its most prominent productions. This tendency dates back to the days of the silent movies and it is a practice that remains along the historiography of the cinema in the sound era. This interest is justified because books and movies share a common interest in narrative and, on the other hand, because both artistic languages benefit from this dialogue, exploring new frontiers that offer expressive possibilities each time the film gives an interpretation of the original text. Furthermore, national literature and movies represent an identity legacy that witnesses a unique cultural heritage. In the case of the classical literature, beyond the book's patrimonial value stands the temporal validation and generational identification by the recognition of common references and by the repository of knowledge which motivates a social and cultural reflection.

This close relationship between literature and cinema, anchored under the sign of adaptation, approaches not only two important cultural forms of expression, but also provides a privileged observatory to reveal how a society represents itself through the fiction. In this sense, throughout this text, the author intends to develop an

\footnotetext{
* Acknowledgments: FCT and CI \& DETS (Center for Studies in Education, Technology and Health, Polytechnic Institute of Viseu) (PEst-OE/CED/UI4016/2014), CITAR (Centre for Research on Science and Technology in Arts) (PEst-OE/EAT/UI0622/2014) POCI 2010, Portuguese Government and the European Union (FEDER).

Filomena A. Sobral, Ph.D., professor, School of Education, Polytechnic Institute of Viseu and CITAR Portuguese Catholic University.
} 
analytical perspective of the updated filmic adaptation of The Crime of Father Amaro (2005), a canonical novel written in 1880 by the renowned Portuguese author Eça de Queiroz, to observe the Portuguese identity portrayed by the movie and, at the same time, to study the transformational process of the adaptation.

The analysis reflects on the feature film The Crime of Father Amaro directed by Carlos Coelho da Silva, because it is an updated transposition of the 19th-century Portuguese novel. This contemporary version provides a modern-day portrait of the Portuguese identity and, on the other hand, the fact that it is an adaptation of a novel by Eca de Queiroz motivates us to highlight the influence of an author who is considered a remarkable international ambassador of the Portuguese identity (Guerra da Cal, 1980). Eca de Queiroz is actually considered a brilliant observer of Portugal and of the Portuguese society (Monica, 2001), whose books have been adapted in a transnational context throughout the years.

The methodology used in this paper aims to describe and explain, allowing us to review important concepts associated to the literary adaptation, as well as questions related to the specificity of the up to date adaptations and also the Portuguese cultural representations and identity. The methodological approach is based on a qualitative content analysis. Therefore, it is established a dual task which begins to decompose the movie into its constituent elements (decomposition/description) and then it is endangered connections between these data to understand and explain (rebuild/interpret) (Gomez Tarín, 2010). This involves seeing the movie, identifying the narrative structure and its basic components and distinguishing between thematic fields to relate all this issues with the novel. Rejecting an approach centered on the textual fidelity, the perspective that was adopted is based on a model that considers the evaluation of the individual qualities of the adaptation. Consequently, it was developed a detailed analysis not only of the iconographic elements but also of the narration aspects, reflecting on the features of the filmic product in order to offer a possible interpretation of the dramatic unity under review. This meticulous process allows us to explore distinctive qualities of the transposition and attempts to emphasize the filmic individuality to characterize not only the production itself, but the national identity represented as well.

\section{The Novel}

The Crime of Father Amaro (1880) is a 19th-century novel which was first published in 1875 in the form of serials in the Western Magazine (Revista Ocidental), then it appeared as a book in 1876 and finally, in 1880, the third version of this narrative was released According to Reis (2005, p. 17) the final proposal of The Crime of Father Amaro is "an adult and mature" work of art.

The Crime of Father Amaro tells the story of Amaro Vieira, a young priest who, upon the death of the Leiria's Cathedral cleric, is appointed to replace him. In that little country town, another cleric (Cónego Dias), who is Mrs. Augusta Caminha lover, arranges accommodation for Father Amaro in her house, where her daughter Amelia, a beautiful 23 year old girl also lives, as well as her paralytic old aunt Gertrude. Installed in that religious residence, under the silent consent of all who attend the devout evenings of the two ladies, Amaro and Amelia initiate a tempestuous love affair. Advised by his servant Dionysia, the young priest begins to have romantic encounters with Amelia under disguise of preparing her for a nun. However, misfortune looms upon the priest when he knows that Amelia is pregnant. To get rid of the situation the first idea of Amaro is to marry Amelia with a previous boyfriend, but soon he knows that the boy has emigrated to Brazil; the second hypothesis is to send Amelia to give birth in a distant place. When the baby is born Amaro gives him to a nanny who killed 
all the babies who she received to take care. Weakened after the childbirth and imploring for her son, Amelia dies. Cowardly, Amaro departs without attending her funeral. He reappears some years later, in 1871, remorseless and even as a priest in a parish of Lisbon.

The Crime of Father Amaro is a novel that deals with a controversial central theme and it represents the literary evolution of Eça de Queiroz. Whereas the first version of the novel is established in a moment where the writer was outlining his style, in the two following versions of the novel there is a clear link to the Realism. This literary movement proposes a reformulation of ideas and literary models and symbolizes the preference for the detail, description and use of adjectives, as well as the use of new forms of expression. Furthermore, there is an enthusiasm for more controversial topics such as sex, incest, adultery and human fragilities, experienced by weak characters who give up to their fatal instincts. In a more radical level of these ideas emerges the Naturalism, a literary school that advocates on behalf of detailed observation of the surrounding reality and emphasizes the critical role of inheritance and environment in determining individual's behaviors. Equally characteristic of naturalistic novels is the construction of dialogues that resemble the spoken language, which results in believable conversations and gives the book a contemporary dimension, as if we were reading a text that is always new.

Influenced by these features, The Crime of Father Amaro is a narrative that focuses not only on the crime of a young priest, but represents the crimes of other amoral religious, as well as the sins of the parishioners who represent a provincial and retrograde society. All this puts emphasis on the social observatory undertaken by Eça de Queiroz. For this reason the novel has a title-The Crime of Father Amaro and a subtitle-Scenes of a Devout Life, thus, extending the universe of the novel. The Crime of Father Amaro accomplishes a socio-cultural critical process drawing attention to what Moura (2004, p. 502) considers to be the "revelation of an illiterate and fearful society, hidden behind concepts and prejudices that they are not aware of".

In terms of the dominant themes of this novel, apart from the question of the priesthood without vocation, Eça de Queiroz underlines other subjects that concerned him, such as education, hypocrisy, political corruption, fraudulent journalism, women's status and domestic unhappy life, located in an extremely social and mental well-characterized scenario (Reis \& Milheiro, 1989). It emerges, therefore, the social environment and the small social groups where the characters move as responsible for the moral degradation of the protagonist. The construction of the fictional individuals is also object of meticulous attention by the 19th-century author because for him the characters are, at the same time, a product of the society and a mirror of that same society. Moreover, they also appear as critical tools and at the same time they are extremely credible.

Antero de Quental (2004), another well-known Portuguese canonical author, thinks that The Crime of Father Amaro is "the best example of Portuguese social psychology" (p. 7) because in it Eça denounces a devout life of a Portuguese province, the small parochial ambitions, the intriguer within the private and social life and the ridiculous figure of some fictional beings that allude to members of the real community. Under the irony that The Crime of Father Amaro is "just, basically, a plot of clerics and devotes whispered in the shade of an old Portuguese province cathedral" (Queiroz, 2004, p. 13), the canonical author starts a narrative that is not simple and represents a critical view towards the delay of Portugal.

Therefore, it is evident that The Crime of Father Amaro highlights several controversial issues with the "purpose of social intervention with strong ideological motivation" (Reis, 2005, p. 60). The canonical author condemns the inaction of the Portuguese and underlines the retrograde attitude of those who live dazzled by the 
foreign influence and are unable to produce knew knowledge autonomously. On the other hand, the 19th-century writer illustrates a country that is dominated by a political, journalistic and intellectual elite which is characterized by the mediocrity. The national parochialism emerges in contrast to European progress. However, despite his tendency to caricature, Eca de Queiroz also shows a perspective of hope that progress destroys both apathy and delays which dominates the nation. Therefore, this is the starting point for a cinematic representation that gave rise in 2005 to a Portuguese film settled in the XXI century.

\section{The Filmic Transmutation}

In his letter to Augusto Fábregas, on 6th May 1890, Eça de Queiroz reveals admiration for the great interest in the adaptation of The Crime of Father Amaro for theater. He writes that "I never thought this novel as being capable of dramatization" (Queiroz as cited in Matos, 1993, p. 37). However, in The Crime of Father Amaro there are actions which are truly dramatic (Andrade as cited in Matos, 1993, p. 37). The truth is that this novel originated not only theatrical adaptations, but also filmic and television versions.

The Crime of Father Amaro (2005), apart from being the Portuguese most successful film in terms of number of viewers $(380,671$, ICA, 2009, p. 37), focuses on a subject that seems to be pleasing the Portuguese audiences. Indeed, the other Portuguese film that previously held the viewers record was Temptation (1997) directed by Joaquim Leitão, with 361,312 viewers (ICA, 2008, p. 39). This film was also based on the story of a forbidden love between a priest and a parishioner.

The 2005 filmic adaptation of The Crime of Father Amaro, although has its roots in the 19th-century novel, presents quite creative reinterpretations, which allows us to catalogue this sort of filmic adaptation as a free adaptation according to Doc's Comparato typology (1993). In this type of adaptation it is common to emphasize the dramatic aspects of the text to create a new structure. This is what, effectively, the filmic transmutation of The Crime of Father Amaro materializes, emphasizing the desire and celibacy of priests and transposing the story to an urban context in the 21 st century. Therefore, the main subject of the film questions once more the celibacy and focuses on the fictionalization of the contemporary living of the priests in a Lisbon parish. Moving away from the source text, the process of metamorphosis involves other issues, such as delinquency, violence and problematic experiences within a social district. The adaptation also focuses on the question of social solidarity. In this sense, in parallel with the central theme of the priests' celibacy, the film accentuates a message of social solidarity, drawing attention to a subplot included in the narrative, to the reality of Lisbon's problematic neighborhoods.

Thus, the film dramatizes criminality problems commonly associated to violent districts, and at the same time it underlines values such as solidarity, inclusion, rehabilitation and reintegration into society. The Parochial Centre attached to the church emerges as a space that brings together individuals and resources that are seeking to organize activities in order to raise funds to help the needy people and, secondly, it also develops a series of educational initiatives, training and basic health care.

In the Portuguese adaptation of The Crime of Father Amaro the subjects, as well as dialogues and scenes, are represented in an impetuous manner, using sex scenes, physical aggression, violence and, sometimes, obscene language. On the other hand, the film also fictionalizes controversial issues, such as suicide or child abuse. Therefore, alongside with the problems experienced within the Catholic Church, such as corruption, sexual scandals, power abuse and excessive behavior of some members of the church community, the filmic adaptation 
focuses on contemporary themes. Although Amaro has always been interested in the female, the idea exhorted by the film is that his integration into a group of corrupt clerics will accelerate his sin. In the filmic transposition Amaro is the sinner and Amelia symbolizes an angry and unstable girl whose childhood innocence was stolen by a cleric who raped her. This disturbed past conditioned Amelia's present. She is inconstant and erratic, always fighting with her mother and boyfriend and putting herself to the test. She defies the limits and is frequently aggressive, but also needy. Like Amelia, Carolina, the subplot's protagonist, is also a problematic young girl.

It is precisely through Amelia and Carolina that other problematic topics are presented on the big screen. Carolina represents the disobedience to her father by becoming involved with the leader of the marginal, appears pregnant and runs away from home in the middle of the night. It is likewise through her that the abortion issue is explored in this fictional narrative text for the first time. Similarly Amelia also reveals family problems, inconsistency and attraction to problematic men, such as the criminal João Eduardo or the hypocritical Amaro. Thus, the character Amelia unveils four major themes: child abuse and rape, on the one hand, and abortion and suicide, on the other hand.

In this sense, in terms of adaptation, the film offers a reinterpretation of Eça's literary heritage putting the emphasis on the creative freedom to renew a canonical narrative. The filmic interpretation adopts the novel as a starting point, especially in terms of theme and main characters, but transforms the substance (Comparato, 1993) to create a contemporary fiction where the dialogues, scenes and actions were written to approach the modern times. Therefore it is an adaptation that distinguishes itself from the classic-novels adaptations, in terms of aesthetic and narrative, and it also proposes a hybrid language (articulating various styles), albeit in a simplified manner.

\section{Identity Portrait}

Eca de Queiroz illustrates Portugal and the Portuguese in a caricatured and ironic way which facilitates the recognition of certain impressions of identity, culture and Portuguese society (melancholic tendency, artificiality and moral weakness (Reis, 2005, p. 40)), that continues to be of interest to the generality of the other arts. The author is responsible for the formation of a very important part of the Portuguese common identity as well as the cultural imaginary and Portuguese collective consciousness (Reis, 2009).

Knowing that the identity of a community defines itself "among many other things, for its models of fiction, and in particular by the dominant models of fiction which it consumes" (Lopes, 1995, p. 13), contributing the fiction to the revelation of important cultural references and identity, we can recognize in the film The Crime of Father Amaro various elements to understand how the Portuguese cinema represents the contemporary society and the Portuguese identity through the filter of fiction. Several examples support the argumentation. First, the representation of the Catholic tradition of the country, not only visible in the historical architecture of the churches, but also evident in various symbols of the Catholicism present in the houses of the characters, such as the image of the Virgin Mary, the representation of The Last Supper (1495-1498) hanging in the living rooms or the crucifix placed above the beds. Also Joaneira's friends symbolize the figure of the Portuguese religious women known for the constant gossip and the continuous lament of many diseases who act as the faithful representative of the traditionalist mentality, evoking the portrait suggested by the philosopher Lourenço (2009, p. 76) that the denigration and the constant criticism "is a tradition among us". 
Paradoxically, the film induces an image of a conservative society, along with the idea of an advanced and cosmopolitan nation. Throughout the times, the traces of the Portuguese identity have been qualified as idealistic and emotional (Dias, 1971), resulting from the maritime adventure that has highlighted not only a spirit of tolerance and adaptability, but also a mind shaped by religious influence that believes in miracles and presages (Lourenço, 2009). Later, under a period of dictatorship, the Portuguese developed a spirit of obedience and the society closed within itself (Gil, 2008). Therefore, the call of the sea and the memory of the great achievements, but also the consequences of the autocracy and the decolonization produced a feeling of present delay in the Portuguese nature which has intensified the sadness and nostalgia (Barreto, 2009). Despite the development of the country and the participation in the European Union, the Portuguese remain traditionalists and inheritors of ancient inertias of which José Gil (2008, p. 88) underlines envy, "passivity, fearful respect for hierarchy, individualism and the lack of future perspectives" and he recalls that what "we need today more than ever, is solidarity "(Gil, 2008, p. 89). According to the same source, the Portuguese society "is among a modernity that never came through and a post-modernity that is gradually invading us" (Gil, 2008, p. 40), this corresponds to an "unfinished modernity" (Machado \& Costa, 1998).

Aware of this context, the filmic adaptation of The Crime of Father Amaro portrays the national identity as paradoxical, between the religious and traditional, but also permeable to outside influences and seeking for modernization. Besides this, the adaptation represents a fictional frame in which the urban family is in collapse, it emphasizes the misunderstanding between parents and children, where children live independent lives and survive through a parallel economy. The film focuses the violence between gangs, the passivity in the face of crime, the respect for the religious authority and a daily living in a neighborhood where the opportunities for a better future are limited. At the same time, the filmic transposition emphasizes a message of solidarity and social inclusion in a creative strategy to captivate audience and approaching the national character.

Another aspect of the Portuguese identity presented in the film The Crime of Father Amaro (2005) is the traditional gastronomy. Based on the argument that the cookery is an important part of the history and cultural traditions of every nation, this characteristic appears as a Portuguese cultural heritage which is perfectly evident in the fiction. So when the character Joaneira receives Amaro into her house, the meal that she serves him is codfish, a popular dish well known and particularly appreciated by the Portuguese. In this scene the presence of the codfish is especially accentuated by a close-up of the fish being placed on the character's plate. To accompany the meal, Amaro drinks red wine, which reminds us of a cultural habit rooted in the national behavior and that Portugal is traditionally a country producer and consumer of wine (Silvério, 2000).

Another Portuguese identity routine shown in the film is the ritual of drinking coffee after the meals. The Portuguese are well-known for drinking strong black coffee in small cups, a practice that remains from the influences of the colonial past. The filmic adaptation under analysis also highlights a typical feature of the Portuguese culture that is the use of diminutives in the oral language. This facet is also emphasized by Eça de Queiroz in his novels, usually for ironic or critical characterization. This is what happens, for example, in the novel The Crime of Father Amaro with the character "Libaninho" whose name is precisely a diminutive and that uses plenty of expressions abundant in diminutives (Queiróz, 2004, pp. 61-62).

A further element of the Portuguese cultural identity that is evidenced by the film is the enthusiasm of the nation for the football. This is perceptible in the adaptation by the soccer games played by the kids and also in the 
decoration of the neighborhood cafe that alludes to one of the greatest football clubs of Lisbon, commonly associated with the popular and historically with the Portuguese capital (Cardoso, Xavier, \& Cardoso, 2007). Football is the sport that mobilizes the country. It is indeed an important factor in the construction of personal and collective identity of a large number of Portuguese citizens (Cardoso et al., 2007, p. 127).

In this sense, the observation of different aspects of the Portuguese identity presents in the fictional translation, such as the language, the gastronomy, the architecture, the religious habits and ways of being, allow us to distinguish peculiarities of the Portuguese and corroborate a specific individuality, though the film doesn't intent to raise questions about it. At the same time, these observations enable the drawing of a cosmopolitan identity, increasingly multicultural and permeable to outside influences, but also highly marked by tradition. This filmic representation explores the identification with a country that searches for modernity, but that, at the same time, is influenced by the conventions and memory. Embarking on a strategy that seeks for recognition, this adaptation confirms not only the traditional identity of the Portuguese, but also disseminates a sketch of the contemporary Portugal, thus establishing a bridge with the modern times. In this sense, the film recalls contemporary anxieties about celibacy, abortion, pedophilia and social problems. It also emphasizes social solidarity, the growth of criminality (drugs and guns), the priesthood without vocation, corruption and journalistic manipulation. All this themes together underline the fact that these are unsolved aspects in the Portuguese society that constitute a fruitful basis for the fictional imaginary. On the other hand, it is a narrative based on the universe of Eça de Queiroz which, by induction, incorporates the identity interrogation and themes that are important to the author, such as celibacy.

\section{From Book to Film}

As the administrator of a Portuguese little country town (Leiria, 1870-1871) Eça de Queiroz could observe a social, human, cultural and religious reality that became his inspiration to write The Crime of Father Amaro, using this scenario as a primordial basis to metaphorically characterize not only the Portuguese identity, but also the country itself.

Being faithful to the book, which is organized into 25 chapters, the film adaptation also starts with the death of Father Miguéis and reveals an image of the religious as amoral. Similarly, in the film, Amaro is introduced into the narrative to replace the Cathedral's minister and he is involved by the sinful environment of S. Joaneira's house where he desires Amelia.

As in the novel, the film shows us, in the form of flashbacks, the childhood of the two protagonists. But, whereas in the case of Amaro the filmic characterization is very close to the literary description (Amaro reveals interest in the opposite sex from an early age and even religious figures raise his carnal desires); when it comes to Amelia the transformational grammar of the adaptation proposes a modern and cosmopolitan character whose past reveals not a fraternal relationship with the priests, but a sinful experience that has an effect on her unstable present.

Similarly to the book, the film suggests the message that education, heredity and environment are fundamental elements to determine the characters present condition. Amelia is shown as a consequence of her dysfunctional family and as a result of her subsistence in a poor neighborhood, which leads to a rootless life and a suicidal nature. Amaro is a young priest whose involvement in a degraded atmosphere will enhance his 
separation from the church and lead him to the transgression without remorse.

Inspired by a literary basis, the film presents around the main characters a group of fictional beings that contribute to illustrate the social context portrayed. But while in the novel these figures are meant to critique religious fanaticism, the parochialism and the retrograde mentality of the country, in the film the characters appear as clichés to identify social groups easily recognizable (such as the religious women, homosexuals, delinquents or amoral priests) and to integrate themselves in a scenario that aims to draw attention to the cosmopolitan current action rather than to dialogue or to the psychological profile of the characters. Thus, while in the novel the characters "claim a social and cultural representativeness adjusted to a critical purpose" (Reis, 2005 , p. 87), in the film the interventions are simplified in order to emphasize sexual and action scenes that include aesthetic and diegetic influences from the North-American action series, from the Portuguese soap operas and from the television journalism of sensationalist propensity (Baptista, 2008). Therefore, although in the novel the characters are used as social representation; in the adaptation the fictional beings operate as attractive to sustain a narrative of action.

The same can be observed about the thematic line. In fact, in the 19th-century novel the author discusses numerous topics susceptible of critical position, whereas the film focuses on the interpretation issues with no intention of "social protest", but in order to get together a set of controversial elements to attract audiences, such as sex, drugs, crime, arms trafficking, pedophilia and suicide, among others.

The book portrays a patriarchal society where women, passive and submissive, are seen as figures who occupy themselves with the home affairs and with the religious life without social representativeness and the group of men, organized around clerics, control the minds of the faithful. This brings out a society dominated by the lack of individualization and subjectivity. In the literary transposition a multicultural and urban society dominates and social problems emerge with dysfunctional families where religion is in failure and where crime enhances survival through parallel economy. The filmic interpretation highlights the individuality and selfishness, hence the appeal of the plot to solidarity and social rehabilitation.

Both narratives, literary and filmic, accentuate an ending in which the priest emerges not only unpunished for his crimes, but continues his life as a conqueror. However, the novel takes the final episode to bring to light the "crisis of individual conscience" (Reis, 2005, p. 62), the dissolution of moral responsibility and the Portuguese conformist nature. On the other hand, it denounces the decadence, the paralysis and the stultification of the nation which is closed to the progressive ideas that erupted in Europe. The author's irony is revealed in its entire splendor in the proclamation that the foreigners envy Portugal (Queiróz, 2004, p. 500). The film, in turn, accentuates an ending in which the carnal element explored throughout the adaptation stands out, filling the screen with a beautiful female who insinuates herself to Amaro. The focus goes to the aesthetic image and not for any ideological, social or moral content. Therefore, this ending emphasizes the sensorial appeal but not the critical reflection.

\section{Conclusion}

It is observed, therefore, that despite having as starting point a challenging Eça de Queiroz 19-century narrative, the film adaptation of The Crime of Father Amaro presents aspects of the Portuguese society and also the Portuguese identity that continue to be a topic of discussion even today. It is a reinterpretation that emphasizes especially the sexual content and the action scenes in a suburban current reality. 
In the film, it prevails a popular and commercial narrative model. The way the topics are represented in the movie does not complicate the themes, but they are used in a simple approach which combines elements of action, spectacle and sensationalism in order to please the contemporary viewer. There is then a different approach from The Scenes of a Devout Life (the subtitle of The Crime of Father Amaro, 1880) of Eça de Queiroz and its critical point of view directed to the whole of the Portuguese society. At the same time, there is a combination of a wide range of subjects susceptible to pleasing a lot of heterogeneous receivers.

In terms of identity, the Portuguese society represented through the fiction film is traditional and conservative, but simultaneously modern and cosmopolitan. The national character is fictionalized as uncritical, conformist and contradictory. The contemporary reality is illustrated as full of contrasts, a city where historic heritage and the manifestations of the modern coexist in an unequal social reality where the poor neighborhoods highlight the differences. Nevertheless, while national identity is mirrored along the film, the adaptation does not complicate or questions, but only portrays in order to motivate proximity and identification

In this sense, the film is a controversial recreation that articulates polemic components (such as crime, priests, sex, violence, celibacy) in an urban setting where action and eroticism combine together to activate the voyeuristic propensity of the spectators. While the novel is a social observatory where the author develops a critical view of the socio and cultural through fictional characters, the film brings into play sex, action and contemporary stereotype characters. Thus, the bond between the film and the canonical novel serves only to exploit the narrative content and to provide the link between the film and a classic book of the Portuguese literature. It is a transposition that underlines the commercial dimension without complexity. In consequence, the visual representation of the national identity establishes a cinematic paradox of a contemporary society in order to appeal to the recognition and to induce viewing without the intention to lead to questioning or critical reflection on Portuguese society.

\section{References}

Aumont, J., \& Marie, M. (2004). Análisis del film (Analysis of the film). Barcelona: Paidós.

Baptista, T. (2008). A invenção do cinema português (The invention of Portuguese cinema). Lisboa: Tinta-da-china.

Barreto, A. (2009, Novembro 28). Interview, Jornal i. Portuguese Daily Newspaper, pp. 24-27.

Bellour, R. (1995). L'analyse du film (Analysis of the film). Paris: Calmann-Lévy.

Cardoso, G., Xavier, D., \& Cardoso, T. (2007). Futebol, Identidade E Media Na Sociedade Em Rede (Football, media and identity in the network society). Observatório Journal, 1, 119-143.

Carmona, R. (1996). Como se comenta un texto fílmico (Commenting a film text). Madrid: Cátedra.

Casetti, F., \& Chio, F. (1991). Cómo analizar un film (How to analyze a film). Barcelona: Paidós.

Cleder, J. (2012). Entre littérature et cinéma: Les affinités électives (Between literature and cinema: Elective affinities). Paris: Armand Colin.

Comparato, D. (1993). Da criação ao guião (Creating the script). Lisboa: Pergaminho.

Dias, J. (1971). Estudos do carácter nacional português (Studies of the Portuguese national character). Lisboa: Junta de Investigações do Ultramar.

Giannetti, L. D. (2004). Understanding movies. New Jersey: Prentice-Hall.

Gil, J. (2008). Portugal, hoje. O medo de existir (Portugal today. The fear to exist). Lisboa: Relógio d'Água.

Gómez Tarín, F. J. (2010). El análisis de textos audiovisuales (Audiovisual text analysis). Espanha: Shangrila Ediciones. Retrieved from http://www.shangrilaediciones.com/Materiales3-El-Analisis-Textos-Audiovisuales.pdf

Guerra da Cal, E. (1980). Lengua y estilo de Eça de Queiroz. Apêndice: bibliografia queirociana sistemática y anotada e iconografia artística del hombre y la obra (Tomo 3) (Eca de Queiroz language and style. Appendix: systematic annotated bibliography and artistic iconography of the man and his work). Coimbra: Acta Universitatis Conimbrigensis. 
Hayward, S. (2000). Cinema studies: The key concepts. London: Routledge.

Hutcheon, L. (2006). A theory of adaptation. New York: Routledge.

Lopes, J. (1995). Teleditadura—Diário de um espectador (Television dictatorship—a spectator diary). Lisboa: Quetzal.

Lourenço, E. (2009). O labirinto da saudade (The labyrinth of nostalgia). Lisboa: Gradiva.

Machado, F. L., \& Costa, A. F. (1998). Processos de uma modernidade inacabada: Mudanças estruturais e mobilidade social (Processes of an unfinished modernity: Structural changes and social mobility). In J. M. L. Viegas \& A. F. da Costa (Eds.), Portugal, que modernidade? (Portugal, which modernity?) (pp. 17-44). Oeiras: Celta Editora.

Matos, A. C. (1993). Dicionário de Eça de Queirós (Eça de Queiroz Dictionary). Lisboa: Caminho.

Mónica, M. F. (2001). Eça de Queirós (Eça de Queiroz). Lisboa: Quetzal Editores.

Moura, H. C. (2004). Nota final. In E. de Queiroz (Ed.), O Crime do Padre Amaro (The Crime of Father Amaro) (pp. 501-503). Lisboa: Edição Livros do Brasil.

Naremore, J. (2000). Film adaptation. New Jersey: Rutgers University Press.

Portugal. Instituto do Cinema e do Audiovisual [ICA]. (2008). Anuário estatístico 2008. (Statistical yearbook 2008). Lisboa: Instituto do Cinema e do Audiovisual.

Portugal. Instituto do Cinema e do Audiovisual [ICA]. (2009). Anuário estatístico 2009 (Statistical yearbook 2009). Lisboa: Instituto do Cinema e do Audiovisual.

Queiroz, E. de (2004). O crime do padre Amaro (The crime of father Amaro). Lisboa: Edição Livros do Brasil.

Quental, A. de (2004). Carta inédita sobre O Crime do Padre Amaro (Unprecedented letter about The Crime of Father Amaro). In E. de Queiroz (Ed.), O Crime do Padre Amaro (pp. 7-9). Lisboa: Edição Livros do Brasil.

Reis, C. (2005). O essencial sobre Eça de Queirós (The essential about Eça de Queiroz). Lisboa: Imprensa Nacional Casa da Moeda.

Reis, C. (2009). Eça de Queirós (Eça de Queiroz). Lisboa: Edições 70.

Reis, C., \& Milheiro, M. R. (1989). A construção da narrativa queirosiana. Lisboa: Imprensa Nacional Casa da Moeda.

Seabra, J. (2011). África nossa-O Império colonial na ficção cinematográfica portuguesa 1945-1974 (Our African-Portuguese Colonial Empire in fiction film 1945-1974). Coimbra: Imprensa da Universidade de Coimbra.

Serceau, M. (1999). L'adaptation cinématographique des textes littéraires (The film adaptation of literary texts). Liège: Éditions du Céfal.

Silvério, M. C. (2000). Análise do mercado de vinho e das zonas vitivinícolas nacionais. Posicionamento, segmentação, preferências e atitudes (Analysis of the wine market and national wine regions. Positioning, segmentation, preferences and attitudes). Universidade de Évora, Évora.

Sinyard, N. (1986). Filming literature: The art of screen adaptation. London: Croom Helm.

Vanoye, F. (2011). L'adaptation littéraire au cinéma (The literary film adaptation). Paris: Armand Colin.

Vanoye, F., \& Goliot-Lété, A. (1994). Ensaio sobre a análise fílmicaz (Essay on the film analysis). São Paulo: Papirus.

Welsh, J. M., \& Lev, P. (2007). The literature/ film reader: Issues of adaptations. California: Scarecrow Press. 